\title{
Time Series Evidence On The Structure Of Interindustry Relationships
}

\author{
Frank GirRatANi AND P. D. MCNELis* \\ INTRODUCTION
}

The identification of industrial groups through data on interindustry relations is widely thought to yield information of potential value in efforts to address problems of regional economic stagnation. The application of this information in matters of economic policy presupposes the existence of instruments by which the activity of groups so identified may be influenced. It also presupposes that the information gained by the application of analytical techniques to cross-section data permits insight on the nature of relations between industries over time. The intent of this paper is to demonstrate that statistical examination of time series data on industrial activity can permit a fuller appreciation of the nature of significance of interindustry relations.

\section{THE ROLE OF TIME SERIES EVIDENCE IN THIS CONTEXT}

Recently, Czamanski and de Q. Ablas [5] compared several techniques that have been applied to the grouping problem. The techniques can be distinguished by their potential use in identifying industry groups whose members locate in spatial proximity to one another (industrial complexes) or in identifying essentially aspatial groupings (industrial clusters). A common characteristic of many such techniques is that substantial use is made of input-output data on industrial transactions as a basis for identifying relevant groups. Czamanski [4], for example, applies multivariate techniques in a 172 order input-output table for the U.S. economy in order to identify sixteen industrial clusters. Regression analysis is then applied to employment data across SMSA's adding a spatial dimension, and therefore offering information on associated complexes. Others, in contrast, have applied graph theoretic techniques to transactions data (cf. Campbell [3]) in order to identify industrial groupings by alternative statistical criteria. ${ }^{1}$

Information of this nature (based on interindustry transactions) relies on data of an essentially static nature. The input-output table is a social accounting array of economic activity in a single year. It reflects the outcome of market decisions in that period of time but does not provide information on historic relationships among industries so

\footnotetext{
*The authors are respectively Assistant Professor, Department of Economics, University of Pittsburgh, Pittsburgh, PA 15260 and Assistant Professor, Department of Economics, Georgetown University, Washington, D.C. 20057. They wish to acknowledge the programming assistance of Mr. A. L. Loviscek, Research Assistant, Regional Research Institute, West Virginia University, Morgantown, West Virginia. Partial funding for this study was provided by the Faculty of Arts and Sciences' Research Grants Committee, University of Pittsburgh.
} 
described. Knowledge of the structure of interindustry relationships over time can serve two purposes. First, it permits the critical evaluation of groups identified by the (static) grouping algorithms. The relationships between industries in groups that are identified by interindustry transactions may or may not be evidenced in their historical patterns of growth, and analysts should be aware of this in recommending application of these techniques. Second, the time series evidence permits the identification of key (dominant) industries within groups. Industries whose activity has historically influenced that of others related to it by interindustry transactions but who have, in turn, been least affected by the extent of activity in these related industries may be effective vehicles of economic policy.

It may be useful to view the role of this evidence as providing a necessary bridge between theory and policy. The methodological framework for the application of information of industry groups in matters of public policy has not been clearly established. Many individuals view grouping algorithms and suggestions of their usefulness for policy purposes in a purely descriptive context. In this view, the algorithms, however simple or complex, represent a mechanism for bringing order to data. They permit the identification of groups that may not have been otherwise obvious, and data analysis in this context is one step in a descriptive-inductive process. Of course in this case, one faces the perennial inductive problem, i.e., generalizing from these observations.

As an alternative one might view the process in a deductivenomological context. There is a very loosely organized body of literature (theory) suggesting the significance of agglomeration economies in regional growth and development. Analysts that argue for the usefulness of the information provided by grouping algorithms for economic policy may do so by recourse to this literature. Evidence exists (some would argue that it is quite casual evidence) on the relationship between interindustry linkages and agglomeration economies (cf. Tybout and Mattila [19]). If under certain circumstances agglomeration economies influence regional growth then groups of industries identified on the basis of interindustry transactions become possible vehicles of policy. ${ }^{2}$

The qualifier "under certain circumstances" is all important in distinguishing the inductive from deductive-nomological approaches. In the latter context the role of theory is to specify those conditions with some definiteness. Our obvious lack of ability in this respect is testimony to the incompleteness of regional economic growth theory. In any event, the argument that interindustry relations reflect agglomeration economies and therefore that growth of one industry in a group should be statistically related to the growth of other industries in that group stands as an explanatory economic hypothesis (Giarratani [8]). That hypothesis may be derived from a very incomplete theoretical framework but it nevertheless represents the basis for belief or doubt in the policy relevance of these groups. As such, time 
series evidence on the relationship between changes in the output of industries within an identified group constitutes a necessary element in the process of verification (falsification) of theory that has to this point been ignored in the literature. That is, we should seek evidence on whether or not the observed patterns of growth for industries in groups that are identified by these algorithms are consistent with this hypothesis.

By supplementing input-output data with time series on industrial output or income for comparably defined sectors, it is possible to establish evidence of this kind. The statistical analysis presented in this paper demonstrates a technique for restricting membership in an industrial group to industries whose historical pattern of growth is consistent with the explanatory hypothesis (outlined above) on which associated policy rests. It will also be shown that this analysis may provide a means of identifying dominant industries within groups.

\section{TIME SERIES ANALYSIS OF CAUSAL PATTERNS}

Granger [10] offers a statistical technique for identifying causal patterns in the relationships between time series variables that has recently been applied in a number of different contexts, especially with regard to the issue of causality between money and income. (Sims [17] and Mehra [14]). The technique requires that the time series under investigation, variables $\mathrm{X}$ and $\mathrm{Y}$, be transformed into covariancestationary stochastic variables $\mathrm{x}$ and $\mathrm{y}$ with $\mathrm{E}(\mathrm{x})=\mathrm{E}(\mathrm{y})=0$. This transformation is accomplished by detrending the data in a spectral preprocessing procedure. Each variable is regressed against time and a constant term. The original vector is then replaced with the residual regression, thereby removing time-dependence from the original data. ${ }^{3}$

To test for patterns of causal relationships between two variables, the method of least squares is used to estimate the linear regression of the detrended series $\mathrm{x}(\mathrm{t})$ and $\mathrm{y}(\mathrm{t})$ on lagged $\mathrm{x}$ 's and $\mathrm{y}$ 's:

$$
\begin{aligned}
& \mathrm{x}(\mathrm{t})=\sum_{\mathrm{i}=1}^{\mathrm{n}} \hat{\mathrm{a}}(\mathrm{i}) \mathrm{x}(\mathrm{t}-\mathrm{i})+\sum_{\mathrm{i}=1}^{\mathrm{n}} \hat{\mathrm{e}}(\mathrm{i}) \mathrm{y}(\mathrm{t}-\mathrm{i}) \\
& \mathrm{y}(\mathrm{t})=\sum_{\mathrm{i}=1}^{\mathrm{n}} \hat{\mathrm{b}}(\mathrm{i}) \mathrm{y}(\mathrm{t}-\mathrm{i})+\sum_{\mathrm{i}=1}^{\mathrm{n}} \hat{\mathrm{f}}(\mathrm{i}) \mathrm{x}(\mathrm{t}-\mathrm{i})
\end{aligned}
$$

where $\hat{a}, b$, ê, and $\hat{f}$ are the least squares estimates. ${ }^{4}$ On the null hypothesis that $y$ does not cause $x$, the parent parameters e(i), $i=1, \ldots$, $\mathrm{n}$ should equal zero. Similarly, on the null hypothesis that $\mathrm{x}$ does not cause $y$, the parent parameters $f(i), i=1, \ldots, n$ should be zero. For $x$ to be strictly exogenous with respect to $y$, and thus a unidirectional cause of $y$, a joint test of the estimates $\hat{e}(i), i=1, \ldots, n$ should be zero while the 
parent parameters $f(i), i=1, \ldots, n$ should be significant. Finally, to show bidirectional feedback between $\mathrm{x}$ and $\mathrm{y}$, a test of the estimates ê(i) and $\hat{f}(i), i=1, \ldots, n$ must be significant.

The application and interpretation of Granger's causality tests have raised many controversies in econometric analysis. Zellner [20] in particular, has argued that the concept of causality implied in these tests is quite distinct from the philosophical definition of causality (see Feigl [7] or Hempel [11] that relies on general laws as a basis for causal explanation. By Granger's test we hope to bring evidence to bear on the validity of an hypothesis that may be of considerable policy relevance. This is accomplished by applying Granger's test for causality to pairs of industries that have been identified as being significantly linked by one of these techniques. It should be emphasized that in applying this criterion we do not suggest that it is possible to circumvent the formidable difficulties that arise in coming to understand causal factors in the philisophical sense raised by Zellner.

\section{THE GROUPING ALGORITHM}

As suggested by Campbell [3], Slater [18] has extended graphtheoretic analysis of interindustry data to network analyses. The graph-theoretic approach to the identification of industry groups begins by assigning zero or unit weights to transactions. Slater's technique in contrast uses continuous data in order to identify direct and indirect industry links. In a first stage procedure, the intial inputoutput transactions table is adjusted in a biproportional algorithm so that all industries are characterized as having identical levels of input and output. ${ }^{5}$ The resultant matrix may be interpreted as the solution to an RAS problem (Bacharach [1]). Intuitively, they are estimates of the transactions that would occur in the absence of scale differences across industries. Slater $[18$, p. 2$]$ argues that this procedure “... permits attention to be concentrated on interindustrial interaction-i.e., structural integration. The magnitudes of the flows between pairs of industries are [otherwise] confounded with the values of total outputs and inputs."

The biproportionally constrained transactions offer information on industrial linkages. In the second stage of this procedure, groups of industries are identified on the basis of these transactions. Two industries are said to be joined if the transaction so constrained exceeds some threshold level. The threshold may be systematically lowered to identify increasingly complex groupings, thus giving a hierarchy of linkages within an industry group. ${ }^{6}$

Graph-theoretic procedures have been criticized for not making full use of the data that is available from input-output transactions tables (cf. Czamanski and de Q. Ablas [5]). The application of the Granger test to examine linkages between industries is independent of the grouping technique employed, however. In this respect, it is only required that 
the industry definitions correspond to available time series information. Slater's procedure does offer a reasonable criterion for analyzing interindustry linkages and will serve adequately for an illustration of the additional information that can be brought to bear on related matters by making use of time series data.

\section{DATA AND RESULTS}

The biproportional algorithm described above has been applied to an input-output transactions table (Loviscek, et al [13]) describing economic activity in the state of West Virginia for the year 1975. This table of interindustry flows updates the original West Virginia inputoutput model (Miernyk, et al [15]) and conforms to the same sectoral definitions. Time series data on income received by two-digit SIC for the region are available from BEA [2] for the years 1958-1977. The input-output industry definitions did not correspond exactly to the BEA time series. It was therefore necessary to aggregate the 48 order West Virginia table to a 31 order matrix with sectors corresponding to the BEA data.

While the clustering algorithm described above can be applied to any square matrix, attempts to identify industry groups are severely limited by an aggregation of this magnitude. The examples provided, however, are sufficiently illustrative of the nature of information that can be obtained by this supplementary analysis. We have concentrated the time series investigation of interindustry linkages to pairwise analysis of industries. One group of three industries was identified, and pairwise analysis of its members is also provided.

Table 1 presents the results of the Granger causality test for the three industrial groups identified by the application of Slater's algorithm. ${ }^{7}$ Group 1 consists of three member industries (eating and drinking establishments, food and kindred products, and agriculture). This group was examined for causal interaction in pairwise analyses, Groups 1a, 1b, and 1c in Table 1. Group 2 consists of the utilities industry and coal mining, while Group 3 pairs instruments and related products with oil and gas extraction.

Evidence on the structure of relationships within these groups may be seen by an examination of the partial F-statistics in the last column of Table 1. Within group 1a the partial F-statistics show that data on income in the food and kindred products industry improves the forecasts of activity associated with eating and drinking establishments, while the latter has little effect on forecasts of income in food and kindred products. By Granger's criterion, activity in the food and kindred products industry may therefore be interpreted as a "unidirectional cause" of that in eating and drinking establishments since there is little evidence of feedback from the latter to food and kindred products. 
TABLE 1

GRANGER'S TEST OF CAUSALITY IN INTERINDUSTRY RELATIONSHIPS

\begin{tabular}{|c|c|c|c|}
\hline $\begin{array}{l}\text { Industrial } \\
\text { Group }\end{array}$ & $\begin{array}{l}\text { Dependent Variable } \\
\text { In Regression }(y)\end{array}$ & $\begin{array}{c}\text { Lagged Independent } \\
\text { Variable in } \\
\text { Regression }(\mathrm{x}) \\
\end{array}$ & $\begin{array}{l}\text { F-Test of Causal } \\
\text { Influence of } \mathrm{x}, \\
\mathrm{F}(3,11)^{\mathrm{a}}\end{array}$ \\
\hline $1 \mathrm{a}$ & $\begin{array}{l}\text { Eating \& Drinking Est. } \\
\text { Food \& Kindred Prds. }\end{array}$ & $\begin{array}{l}\text { Food \& Kindred Prds. } \\
\text { Eating \& Drinking Est. }\end{array}$ & $\begin{array}{l}13.36 * * * \\
2.63\end{array}$ \\
\hline $1 b$ & $\begin{array}{l}\text { Agriculture } \\
\text { Food \& Kindred Prds. }\end{array}$ & $\begin{array}{l}\text { Food \& Kindred Prds. } \\
\text { Agriculture }\end{array}$ & $\begin{array}{r}1.74 \\
.89\end{array}$ \\
\hline $1 \mathrm{c}$ & $\begin{array}{l}\text { Agriculture } \\
\text { Eating \& Drinking Est. }\end{array}$ & $\begin{array}{l}\text { Eating \& Drinking Est. } \\
\text { Agriculture }\end{array}$ & $\begin{array}{l}.89 \\
.44\end{array}$ \\
\hline 2 & $\begin{array}{l}\text { Utilities } \\
\text { Coal Mining }\end{array}$ & $\begin{array}{l}\text { Coal Mining } \\
\text { Utilities }\end{array}$ & $\begin{array}{l}3.86^{*} \\
.06\end{array}$ \\
\hline 3 & $\begin{array}{l}\text { Instruments \& Related } \\
\text { Prds. } \\
\text { Oil \& Gas Extraction }\end{array}$ & $\begin{array}{l}\text { Oil \& Gas Extraction } \\
\text { Instruments \& Related } \\
\text { Prds. }\end{array}$ & $\begin{array}{c}17.36 * * * \\
9.30 * *\end{array}$ \\
\hline
\end{tabular}

NOTE: The data for the $\mathrm{x}$ and $\mathrm{y}$ variables in each group represent the detrended income flows of each industry listed in the second and third columns. The regressions were fitted to the period 1958-76 with annual data. The regression equation of $y$ on lagged $y$ and lagged $x$ was estimated by OLS in the following form, with a lag of 3 years for each variable:

$$
y(t)=\Sigma \hat{a}(i) y(t-i)+\sum b(i) \times(t-i)
$$

The F-test in column 4 is a test of the null hypothesis that the parameters $b(1), b(2)$, and $b(3)$ are zero in the above regression equation.

\footnotetext{
a Degrees of freedom

* Significant at the $5 \%$ level; $\mathrm{F}_{\mathrm{c}}=3.59$;

$* *$ Significant at the $1 \%$ level; $\mathrm{F}_{\mathrm{c}}=6.22$;

$* * *$ Significant at the $.1 \%$ level; $\mathrm{F}_{\mathrm{c}}=11.56$

Group $1 \mathrm{~b}$ and $1 \mathrm{c}$ show little interaction between agriculture and the food and kindred products sector or eating and drinking establishments. Information on activity in these industries does little to improve forecasts of agricultural activity. In turn, information on agriculture does little to improve forecasts in either food and kindred products or eating and drinking establishments.

In summary, the analysis of Group 1 indicates that the only causal relationship is between the food and kindred products and eating and drinking establishments. There is no further evidence of unidirectional causality or feedback among the three industries in this group. In this instance, supplementary time series data has offered useful informa-
} 
tion on the behavior of industries known to be related by interindustry transactions. This empirical evidence offers support for the dominance of the food and kindred products industry in this group, though doubt is cast on the significance of the membership of the agricultural sector. Note that by Granger's criterion we would have to reject the explanatory hypothesis offered above which suggests that all members of this group should influence one another's behavior over time. Whatever factors affect the agricultural sector, they do not seem to be captured by interindustry transactions.

The F-tests for Group 2 in Table 1 show that coal mining data improve forecasts of activity in the utility industry, while information concerning utilities does little to improve forecasts of activity in coal mining. The Granger test thus supports the linkage between these industries that is implied by the interindustry information. It offers further statistical evidence on the structure of this relationship that cannot be deduced from the interindustry data alone. Input-output tables do offer directional information in the sense that the flow variable $x_{i j}$ is directional from industry $\mathrm{i}$ to industry $\mathrm{j}$ and a corresponding flow $\mathrm{x}_{\mathrm{ji}}$ may or may not be evidenced in the table (see footnote 6). It is not, however, possible to attribute dominance to either industry simply on the basis of these data though a theoretical argument for dominance could be developed on the basis of knowledge of the particular characteristics of these industries in the region.

Finally, the F-tests for Group 3 show that there is strong interaction between the instruments and related products industry and the oil and gas extraction industry. Information on oil and gas extraction significantly improves the forecasts of instruments and related products and the converse is also true. The bidirectional nature of the relationship between these industries is evident from these tests and a dominant-subordinate ordering is not possible on Granger's criterion.

The validity of the partial F-statistics reported in Table 1 crucially depends on the absence of serial correlation in the residuals of each regression equation. A test for serial correlation using the cumulative periodogram, proposed by Durbin [6], was applied to the regression results reported in Table $1 .{ }^{8}$ The results of the cumulative periodogram tests did not provide sufficient evidence to reject the hypothesis of serial independence in the residuals of the regressions.

\section{CONCLUSION}

It has been argued that evidence on the structure of interindustry relations that is available from an analysis of time series on industrial activity offers useful supplementary information on the nature of industrial groups. The level of sectoral aggregation used in this study did not permit an extensive examination of complex relationships of this sort but the results are nevertheless indicative of the potential power of this technique. Where compatable time series are available for more detailed input-output transactions tables, it would be possible to identify industrial groups whose historical pattern of growth suggest 
directional linkages among member industries. We have shown that groups defined without regard to time series evidence on interindustry relationships may well be inconsistent with the explanatory hypothesis that is implicitly offered as the basis for their policy relevance. It may also be possible to identify one or more dominant members on the criterion that a leader exhibit evidence of causal influence on other industries (by Granger's criterion) with little feedback evidenced from other group members.

REFERENCES

1. Bacharach, M. A. Biproportional Matrices and InputOutput Change, London: Cambridge University Press, 1970 .

2. Bureau of Economic Analysis (BEA), Survey Tables: Personal Income by Major Source and Earnings by 2-Digit SIC. Washington, D.C.: U.S. Department of Commerce, 1978.

3. Campbell, J. "Application of Graph Theoretic Analysis to Interindustry Relationships," Regional Science and Urban Economics, 5 (1975), 91-106.

4. Czamanski, S. Study of Clustering of Industries, Halifax Institute of Public Affairs, Dalhousie University, 1974

5. and L. A. de Q. Ablas, "Identification of Industrial Clusters and Complexes: A Comparison of Methods and Findings," Urban Studies, 16 (1979), 61-80.

6. Durbin, J., "Tests for Serial Correlation in Regression Analysis Based on the Periodogram of Least Squares Residuals," Biometrica 56(1969), 1-15.

7. Feigl, H., "Notes on Causality," Readings in the Philosophy of Science, eds. H. Feigl and M. Brodbeck. New York: Appleton-Century-Crofts, Inc., 1953.

8. Giarratani, F., "The Scientific Basis for Explanation in Regional Analysis," Papers, RSA, 45 (forthcoming).

9. Giarratani, F. and P.D. McNelis, "Time Series Evidence Bearing on Crude Theories of Regional Growth," Land Economics (May, 1980), forthcoming.

10. Granger, C. W. J., "Investigating Causal Relations by Econometric Models and Cross-spectral Methods," Econometrica, 37 (1969), 424-38.
11. Hempel, C. G. Aspects of Scientific Explanation, New York: The Free Press, 1965.

12. Hollis, M. and E. J. Nell, Rational Economic Man, New York: Cambridge University Press, 1975.

13. Loviscek, A. L., et al, The 1975 West Virginia InputOutput Study, Morgantown, WV: West Virginia University Library, 1979.

14. Mehra, Y. P., “Money Wages, Prices and Causality," Journal of Political Economy 85 (1977), 1227-44.

15. Miernyk, W. H., et al Simulating Regional Economic Development, Lexington: D. C. Health and Co., 1970.

16. National Bureau of Economic Research (NBER). TROLL Experimental Programs. Cambridge, Mass.: Computer Research Center for Economics and Management Science, 1974.

17. Sims, C. A., "Money, Income, and Causality," American Economic Review, 62 (1972), 540-52.

18. Slater, P. D., "The Determination of Groups of Functionally Integrated Industries in the United States Using a 1967 Interindustry Flow Table," Empirical Economics 2 (1977), $1-9$.

19. Tybout, R. A. and J. M. Mattila, "Agglomeration of Manufacturing in Detroit," Journal of Regional Science, 17 (1977): 1-16.

20. Zellner, A. "Causality and Econometrics," Three aspects of Policy and Policymaking, Vol. 10 of Carnegie-Rochester Conferene Series on Public Policy. Edited by K. Brunner and A. H. Meltzer. Amsterdam: North-Holland Publishing Co., 1979.

\section{FOOTNOTES}

'As pointed out by Czamanski and de Q. Ablas [5] the ability of a technique to identify spatial groupings is not always well defined. Application of a technique to a small area inputoutput table may yield information with indirect spatial content, while application of the same technique to data for a larger region may not have this implied result.

${ }^{2}$ It should be pointed out that this discussion does not mean to imply that the inductive problem is avoided in this context (see Hollis and Nell [12]).

${ }^{3}$ The detrend alogrithm returns the values $Z^{\prime}, Z^{\prime}=Z_{t}-$ ZFIT $_{t}$, where $\mathrm{Z}$ is the input data, $\mathrm{t}$ denotes the time period, and ZFIT is accomplished by a regression of the form:

$$
\begin{gathered}
\mathrm{Z}=\alpha+\beta \mathrm{t}+\gamma \mathrm{t}^{2}+\epsilon \\
\mathrm{Z}=\mathrm{ZFIT}+\epsilon
\end{gathered}
$$

See NBER [16] "Troll Experimental Program: Spectoral and Cross Spectoral Analysis," for a description of this transformation.

4 In equation (1) and (2) the regressions are specified with $\mathrm{n}$-lagged terms for $\mathrm{x}$ and $\mathrm{y}$. There is no reason for the number of lagged terms to be equal for each variable.
${ }^{5}$ Denote the transactions table XIJ and let $\mathrm{x}_{\mathrm{ij}}$ be the $\mathrm{i}, \mathrm{jth}$ element in this square matrix. The algorithm constrains XIJ to conform to the condition $\Sigma \mathrm{x}_{\mathrm{ij}}=\Sigma \mathrm{x}_{\mathrm{ij}}=\mathrm{c}$ for each sector (where $\mathrm{c}$ is constant $>0$ ).

Thus row and column elements of every sector sum to the same value, $c$.

${ }^{6}$ A distinction should be made between a directed sequence between two sectors $l$ and $k$ and an undirected connection between those sectors. 1 and $k$ are said to be a strong component if there is a linkage from $\mathrm{l}$ to $\mathrm{k}$ and also from $\mathrm{k}$ to $\mathrm{l}$. A weak component simply implies a linkage in either direction. The results presented below are based on weak (undirected) linkages between sectors.

Coefficient estimates for these regressions are provided in Appendix Table 1.

${ }^{8}$ A description of the cumulative periodogram test for serial correlation in the context of a Granger causality test between export and residentiary income may be found in Giarratani and McNelis [9]. 
Appendix Table 1

REGRESSION ESTIMATES OF THE GRANGER CAUSALITY TEST

IN INTERINDUSTRY RELATIONSHIPS

$$
y(t)=\Sigma \hat{a}(i) y(t-i)+\Sigma \hat{b}(i) \times(t-i)
$$

\begin{tabular}{|c|c|c|c|c|c|c|c|c|c|}
\hline $\begin{array}{l}\text { Industrial } \\
\text { Group }\end{array}$ & $\begin{array}{l}\text { Dependent } \\
\text { Variable } \\
\text { (y) }\end{array}$ & $\begin{array}{l}\text { Independent } \\
\text { Variable } \\
(\mathrm{x})\end{array}$ & \multicolumn{6}{|c|}{$\begin{array}{c}\text { Coefficient Estimates } \\
\text { (t-statistics in parenthesis) }\end{array}$} & $\mathrm{R}^{2}$ \\
\hline $1 \mathrm{a}$ & $\begin{array}{l}\text { Eating \& Drinking } \\
\text { Est. }\end{array}$ & $\begin{array}{l}\text { Food \& Kindred } \\
\text { Prds. }\end{array}$ & $\begin{array}{c}0.650 \\
(3.406)\end{array}$ & $\begin{array}{l}-0.086 \\
(-0.430)\end{array}$ & $\begin{array}{c}0.258 \\
(1.273)\end{array}$ & $\begin{array}{l}-0.695 \\
(-2.598)\end{array}$ & $\begin{array}{c}1.208 \\
(3.787)\end{array}$ & $\begin{array}{l}-1.561 \\
(-6.226)\end{array}$ & .869 \\
\hline & $\begin{array}{l}\text { Food \& Kindred } \\
\text { Prods. }\end{array}$ & $\begin{array}{l}\text { Eating \& Drinking } \\
\text { Est. }\end{array}$ & $\begin{array}{c}0.415 \\
(1.725)\end{array}$ & $\begin{array}{c}0.324 \\
(1.130)\end{array}$ & $\begin{array}{l}-1.047 \\
(-4.885)\end{array}$ & $\begin{array}{c}0.047 \\
(0.277)\end{array}$ & $\begin{array}{c}0.259 \\
(1.437)\end{array}$ & $\begin{array}{c}0.284 \\
(1.555)\end{array}$ & .890 \\
\hline $1 b$ & Agriculture & $\begin{array}{l}\text { Food \& Kindred } \\
\text { Prds. }\end{array}$ & $\begin{array}{r}-0.564 \\
(-1.964)\end{array}$ & $\begin{array}{r}-0.587 \\
(-2.092)\end{array}$ & $\begin{array}{r}-0.133 \\
(-0.423)\end{array}$ & $\begin{array}{c}0.007 \\
(0.134)\end{array}$ & $\begin{array}{c}0.106 \\
(1.556)\end{array}$ & $\begin{array}{l}-0.060 \\
(-1.000)\end{array}$ & .509 \\
\hline & $\begin{array}{l}\text { Prds. } \\
\text { Proded }\end{array}$ & $\begin{array}{l}\text { Agriculture } \\
\text { Eating \& Drinking }\end{array}$ & $\begin{array}{c}0.777 \\
(3.721)\end{array}$ & $\begin{array}{c}0.284 \\
(1.094)\end{array}$ & $\begin{array}{l}-1.038 \\
(-4.472)\end{array}$ & $\begin{array}{c}0.322 \\
(0.293)\end{array}$ & $\begin{array}{l}1.516 \\
(1.416)\end{array}$ & $\begin{array}{l}-0.005 \\
(-0.004)\end{array}$ & .848 \\
\hline $1 \mathrm{c}$ & Agriculture & Est. & $\begin{array}{l}-0.656 \\
(-2.314)\end{array}$ & $\begin{array}{l}-0.719 \\
(-2.304)\end{array}$ & $\begin{array}{l}-0.355 \\
(-1.122)\end{array}$ & $\begin{array}{l}-0.013 \\
(-0.271)\end{array}$ & $\begin{array}{c}0.036 \\
(0.738)\end{array}$ & $\begin{array}{c}0.053 \\
(1.078)\end{array}$ & .417 \\
\hline & $\begin{array}{l}\text { Eating \& Drinking } \\
\text { Est. }\end{array}$ & Agriculture & $\begin{array}{c}0.521 \\
(1.546)\end{array}$ & $\begin{array}{c}0.500 \\
(1.522)\end{array}$ & $\begin{array}{l}-0.473 \\
(-1.408)\end{array}$ & $\begin{array}{l}-2.089 \\
(-1.094)\end{array}$ & $\begin{array}{l}-1.089 \\
(-0.519)\end{array}$ & $\begin{array}{l}-0.507 \\
(-0.238)\end{array}$ & .457 \\
\hline 2 & Utilities & Coal Mining & $\begin{array}{c}0.880 \\
(2.149)\end{array}$ & $\begin{array}{l}-0.366 \\
(-0.785)\end{array}$ & $\begin{array}{l}-0.386 \\
(-1.554)\end{array}$ & $\begin{array}{c}0.022 \\
(2.398)\end{array}$ & $\begin{array}{c}0.002 \\
{[: \times \oiint \#]}\end{array}$ & $\begin{array}{l}-0.009 \\
{[-0.794)}\end{array}$ & .744 \\
\hline & Coal Mining & Utilities & $\begin{array}{c}0.568 \\
(1.651)\end{array}$ & $\begin{array}{l}-0.205 \\
(-0.371)\end{array}$ & $\begin{array}{l}-0.021 \\
(-0.047)\end{array}$ & $\begin{array}{l}-4.525 \\
(-0.300)\end{array}$ & $\begin{array}{r}-4.330 \\
(0.251)\end{array}$ & $\begin{array}{c}1.357 \\
(0.148)\end{array}$ & .294 \\
\hline 3 & $\begin{array}{l}\text { Instruments \& } \\
\text { Related Prds. }\end{array}$ & $\begin{array}{l}\text { Oil \& Gas Extration } \\
\text { Instruments \& }\end{array}$ & $\begin{array}{l}-0.135 \\
(-0.542)\end{array}$ & $\begin{array}{l}-0.846 \\
(-3.578)\end{array}$ & $\begin{array}{l}-0.890 \\
(-2.810)\end{array}$ & $\begin{array}{c}0.068 \\
(6.271)\end{array}$ & $\begin{array}{c}0.037 \\
(1.725)\end{array}$ & $\begin{array}{c}0.038 \\
(1.970)\end{array}$ & .870 \\
\hline & Oii \& Gas Extraction & Related Prds. & $\begin{array}{c}0.261 \\
(1.446)\end{array}$ & $\begin{array}{c}0.226 \\
(0.632)\end{array}$ & $\begin{array}{l}-1.291 \\
(-3.987)\end{array}$ & $\begin{array}{c}8.857 \\
(2.142)\end{array}$ & $\begin{array}{l}12.548 \\
(3.199)\end{array}$ & $\begin{array}{l}0.066 \\
(0.012)\end{array}$ & .857 \\
\hline
\end{tabular}

